\title{
NIKAH WAKIL DALAM PERSPEKTIF HUKUM NEGARA DAN HUKUM ISLAM
}

\author{
Muhammad Noor ${ }^{1)}$, Mufrida Zein ${ }^{2)}$ \\ Teknik Informatika ${ }^{1}$, Akuntansi ${ }^{2}$ Politeknik Negeri Tanah Laut \\ email:muhammadnoorpolitala@gmail.com ${ }^{1)}$
}

\begin{abstract}
Abstrak
Di Indonesia ketentuan yang berkenaan dengan perkawinan telah diatur dalam peraturan perundangan Negara yang khusus berlaku bagi warga Negara Indonesia. Aturan perkawinan yang dimaksud yaitu Undang-Undang No.1 Tahun 1974 dan peraturan pelaksanaannya dalam bentuk Peraturan Pemerintah No.9 Tahun 1975. Fenomena tentang prnikahan yang tidak dihadiri oleh mempelai laki-laki atau nikah wakil menjadikan hal tersebut menjadi sebuah pertanyaan besar di kalangan masyarakat awam yang belum banyak mengetahui keadaan tersebut, . Keadaan semacam ini bisa dijelaskan melalui hukum Islam dan hukum Negara.
\end{abstract}

Keywords : Nikah wakil, Perkawinan, Undang-undang No. 1 Tahun 1974.

\section{Abstract}

In Indonesia, the provisions relating to marriage have been regulated in the State regulations specifically for Indonesian citizens. The aforementioned marriage rules, namely Law No. 1 of 1974 and the implementing regulations in the form of Government Regulation No.9 of 1975. The phenomenon of marriage which is not attended by the bridegroom or deputy marriage makes this a big question among the public. layman who do not know much about the situation ,. This kind of situation can be explained through Islamic law and State law.

Keywords : Marriage deputy, Marriage, Law No. 1 of 1974.

\section{PENDAHULUAN}

Perkawinan adalah fitrah yang terjadi pada setiap makhluk ciptaan Allah SWT Al-Qur'an menjelaskan dalam surat Az-Zariyat ayat 49 : "Dan segala sesuatu Kami ciptakan berpasang-pasangan supaya kamu mengingat kebesaran Allah" maka daripada itu manusia pasti mempunyai naluri untuk mencintai pasangan, baik laki-laki terhadap perempuan atau perempuan terhadap laki-laki. Saling mencintai antara insan yang berlainan jenis merupakan kebutuhan biologis, yang hal itu bisa tersalur apabila terjadi perpaduan antara keduanya.

Rasulullah SAW menyerukan kepada ummatnya untuk melaksanakan pernikahan bagi yang sudah siap, dari ibnu Mas'ud Rasullullah SAW bersabda : "Hai para pemuda, barangsiapa diantara kamu yang sudah mampu menikah, maka menikahlah, karena sesungguhnya nikah itu lebih dapat menundukkan pandangan dan lebih menjaga kemaluan, barangsiapa yang belum mampu, maka hendaklah iya berpuasa, karena puasa itu baginya (menjadi) pengekang sahwat”.

Pada zaman sekarang ini banyak orang yang ingin melaksanakan pernikahan, akan tetapi terkendala dengan beberapa permasalahan, seperti jarak dan lain-lain. Sebuah pernikahan layaknya dihadiri oleh mempelai laki-laki yang ingin melaksanakan ijab qobul, namun apa jadinya jika sang mempelai laki-laki tidak bisa berhadir untuk melakukan ijab qobul, dikarnakan sesuatu hal, seperti jauhnya jarak yang tidak 
memungkinkan untuk berhadir pada waktu itu, dan akhirnya pernikahan tersebut diwakilkan oleh seseorang yang telah ditunjuknya. Hal tersebut mengakibatkan timbulnya pertanyaan bahkan permasalahan dimasyarakat yang akan menimbulkan perdebatan di Masyarakat, seperti sah atau tidaknya pernikahan tersebut. Permasalahan ini akan berdampak kepada kemajuan teknologi komunikasi pada saat ini, yang akan menimbulkan pertanyaan baru dan berdampak pada konsekuensi hukum baru seperti bolehkan nikan lewat telepon atau video call.

Di Indonesia ketentuan yang berkenaan dengan perkawinan telah diatur dalam peraturan perundangan Negara yang khusus berlaku bagi warga Negara Indonesia. Aturan perkawinan yang dimaksud yaitu Undang-Undang No.1 Tahun 1974 dan peraturan pelaksanaannya dalam bentuk Peraturan Pemerintah No.9 Tahun 1975. Di samping peraturan perundang-undangan negara yang disebutkan di atas dimasukkan pula dalam pengertian Undang-Undang Perkawinan dalam bahasan ini diatur atau ketentuan yang secara efektif telah dijadikan oleh hakim di Pengadilan Agama sebagai pedoman yang harus diikuti dalam penyelesaian perkara perkawinan, yaitu Kompilasi Hukum Islam di Indonesia yang penyebarluasannya dilakukan melalui Instruksi Presiden RI No.1 Tahun 1991 tentang Kompilasi Hukum Islam (KHI). Kompilasi Hukum Islam disusun untuk melengkapi Undang-Undang Perkawinan dan diusahakan secara praktis mendudukkannya sebagai hukum perundang-undangan meskipun kedudukannya tidak sama dengan itu

\section{METODE PENELITIAN}

Jenis penelitian yang dibahas dalam tulisan ini adalah deskriptif kualitatif. Penelitian deskriptif kualitatif adalah suatu pendekatan yang juga disebut pendekatan investigasi karena biasanya penelitian mengumpulkan data dengan cara bertatapmuka langsung dan berinteraksi dengan orang-orang di tempat penelitian (McMilan \& Schumacher, 2003). Adapun tujuan dari penelitian ini adalah untuk mengungkapkan kejadian atau fakta, keadaan, fenomena yang terjadi. Penelitian ini menafsirkan dengan situasi yang sedang terjadi, sikap serta pandangan yang terjadi di dalam suatu masyarakat, pertentangan antara dua keadaan atau lebih, serta pengaruhnya terhadap suatu kondisi, dan sebagainya.

\section{HASIL DAN PEMBAHASAN}

1. RUKUN NIKAH : Rukun dan syarat nikah menjadi hal yang wajib ada, pada setiap prosesi akan melaksanakan sebuah pernikahan. Ketika seluruh rukun dan syarat ini terpenuhi, maka akan menjadikan sah nya sebuah hubungan pernikahan. Tetapi ketika dalam melaksanakan pernikahan tanpa adanya sebuah rukun dan syarat yang terurut dan tertib, maka tidak akan sah dan berlaku pernikahan tersebut. Rukun dan syarat untuk melakukan sebuah pernikahan ini sejatinya sesuatu yang saling terkait dan tidak bisa untuk dipisahkan. Ketika antara dua hal ini dipisahkan, maka akan mengakibatkan sebuah pernikahan tidak akan bisa berjalan secara lancar. Adapun beberapa hal dalam rukun dan syarat ini menjadi kesatuan dalam tercapainya sebuah pernikahan yang baik.

\subsection{Wali Nikah}

Wali nikah adalah orang yang berhak menikahkan perempuan dengan laki-laki yang sesuai dengan syari'at islam. Wali dalam pernikahan mempunyai kedudukan yang sangat penting, bahkan dapat menentukan sah tidaknya sebuah pernikahan. Pernikahan tanpa wali hukumnya tidak sah atau batal. Secara garis besar wali nikah dibagi menjadi dua macam yaitu wali nasab dan wali hakim. Wali nasab adalah wali karena ada hubungan darah atau kerabatnya yang berhak menjadi wali dan wali hakim adalah orang yang diberi hak oleh penguasa untuk menjadi wali nikah dalam keadaan tertentu dan sebab tertentu. Sebagian ulama diantaranya ulama madzhab syafi' $i$, hambali dan hanafi 
menambahkan bahwa orang yang memerdekakan budak berhak menjadi wali nikah bagi para budak yang yang dimerdekakannya jika tidak ada wali nasab. Adapun syarat wali adalah :

Beragama islam, Baligh, Berakal, Merdeka, Laki-Laki, Adil.

\subsection{Istri}

Seorang istri merupakan salah satu dari dua orang yang akan menjalani pernikahan itu sendiri, akan tetapi bukan setiap wanita bias menjadi istri bagi pria, hanya mereka yang memenuhi syarat-syarat sebagai berikut : Wanita tulen, Tidak sedang melakukan ihram (Haji atau Umrah), Bukan Istri seseorang, Bukan mahrom calon pengantin pria, Tidak dalam masa iddah, Calon Pengantin wanita diketahui oleh calon suaminya, Wanita itu bukan istri yang kelima bagi calon suami.

\subsection{Suami}

Syarat-syarat menjadi seorang suami : Tidak dipaksa, Laki-laki Tulen, Identitasnya diketahui dengan jelas, Harus mengetahui calon istrinya, Tidak sedang ihram (Haji atau Umram), Bukan mahrom calon suami dan halal untuk dinikahi, Muslim.

\subsection{Dua Orang Saksi}

Tidak ada suatu pernikahan kecuali dengan adanya wali dan dua orang saksi yang adil dan jika ada pernikahan tanpa keberadaan mereka maka pernikahan tersebut bathil. Diriwayatkan oleh ibnu Hibban. Adapun syarat menjadi saksi pernikahan adalah : Baligh, Berakal, Laki-laki, Islam, Adil, Tidak Idiot, Tidak Tuli, Tidak Buta, Tidak Bisu, Memahami bahasa yang digunakan saat aqad, Tidak memiliki ingatan yang sangat lemah, Salah satu dari saksi tersebut bukan wali satu-satunya dari calon istri.

\subsection{Aqad (ijab qobul)}

Aqad ijab qobul merupakan rukun yang paling menentukan menjadikan suatu yang haram menjadi halal, dan tidak sah suatu pernikahan tanpa ijab qobul. Adapun ijab diucapkan si wali nikah, sedangkan aqad qobul diucapkan calon suami. Adapun syarat ijab qobul adalah : Harus dengan kalimat kawin dan nikah, Antara ijab dan qobul tidak diselingi oleh kata-kata yang tidak ada tuntunan nikah, maslahat dan sunnah-sunnah dalam aqad nikah, Antara ijab dan qobul tidak diselingi diam yang lama, Antara ijab dan qobul harus sesuai dengan arti dan maksudnya, Aqad tidak digantungkan dengan sesuatu apapun, Tidak menyebutkan batasan waktu, Aqad harus dilafadkan sekiranya didengar oleh orang disekitarnya, Tidak boleh menyebutkan syarat yang merusak tujuan nikah, Si wali dan suami harus tetap keadaannya.

Hasil dari pertanyaan yang ditujukan kepada 10 orang Dosen politeknik Negeri Tanah Laut

\begin{tabular}{|c|l|c|c|}
\hline TABEL 1 \\
\hline 1 & $\begin{array}{l}|c| \\
\text { No }\end{array}$ & Mengetahui & Tidak Mengetahui \\
\hline 2 & $\begin{array}{l}\text { Apakah anda mengetahui tentang nikah } \\
\text { kakil ? anda mengetahui tentang } \\
\text { keabsahan nikah wakil? }\end{array}$ & 2 & 8 \\
\hline 3 & $\begin{array}{l}\text { Apakah anda mengetahui kejadian ini } \\
\text { pernah terjadi di lingkungan anda? }\end{array}$ & - & 10 \\
\hline
\end{tabular}


Fenomena tentang prnikahan yang tidak dihadiri oleh mempelai laki-laki menjadikan hal tersebut sebuah pertanyaan besar di kalangan masyarakat awam yang belum banyak mengetahui keadaan tersebut, contoh kasus : seorang laki-laki yang berada di luar negeri berkeinginan untuk menikah dengan pujaan hatinya yang berada di Indonesia, laki-laki tersebut mewakilkan dirinya kepada lawyer atau orang kepercayaannya untuk menikahi pujaan hatinya tersebut di Indonesia. Bagaimana tinjauan hukum pernikahan seperti ini, kejadian tersebut bisa menjadi permasalahan tersendiri bagi yang belum mengetahuinya. Keadaan semacam ini bisa dijelaskan melalui hukum Islam dan hukum Negara.

2. Hukum Perundang-undangan Negra Republik Indonesia sudah mengatur tentang pernikahan melalui Undang-undang Republik Indonesia No.1 tahun 1974 tentang perkawinan. Adapun penjelasan diatas tentang mempelai pria mewakilkan dirinya untuk melaksanakan pernikahan dijelaskan lebih lanjut dalam buku perundang-undangan kompilasi hukum Islam pasal 29, yang bunyinya sebagai berikut :

2.1. Yang berhak mengucapkan kabul ialah calon mempelai pria secara pribadi.

2.2. Dalam hal-hal tertentu ucapan kabul nikah dapat diwakilkan kepada pria lain, dengan ketentuan calon mempelai pria memeberi kuasa yang tegas secara tertulis bahwa penerimaan wakil atas akad nikah itu adalah untuk mempelai pria.

2.3. Dalam hal calon mempelai wanita atau wali keberatan calon mempelai pria diwakili,maka akad nikah tidak boleh dilangsungkan

3. Dalam syariat Islam, kita mengenal istilah taukil, yang secara harfiyah berarti perwakilan. Seorang yang punya hak dan wewenang tertentu, boleh saja meminta orang lain untuk mewakilkan dirinya. Misal yang sederhana dalam hal persidangan hukum atau akad-akad bisnis. Kita biasa menyaksikan seorang lawyer diminta untuk menjadi wakil penuh bagi seseorang dalam perkara hukum. Misal sederhana yang lain adalah seorang duta besar menjadi wakil atas kepala negara asalnya di negera tempatnya bertugas. Maka dalam syariah yang terkait dengan akad-akad, taukil ini punya kedudukan hukum yang sah. Misalnya seorang pedagang mewakilkan wewenangnya kepada pegawainya untuk menjualkan barang dagangannya. Akad itu sah hukumnya, meski tidak dilakukan langsung oleh pedagangnya. Ditinjau dari hukum Islam tentang keadaan mempelai pria yang mewakilkan dirinya untuk menikah adalah sebagai berikut :

\subsection{Wakil Wali}

Seorang ayah kandung boleh meminta orang lain menjadi wakil atas dirinya dalam menikahkan puterinya. Hal ini lazim terjadi di tengah kita. Bahkan kadang yang terlalu berlebihan. Walaupun sang Ayah kandung itu hadir dalam akad nikah, tetapi masih juga meminta orang lain yang biasanya lebih dituakan untuk menjadi wakil atas dirinya. Misalnya Ayah kandung itu minta ulama setempat, atau tokoh masyarakat tertentu untuk bertindak menjadi wakil atas dirinya. Maka sah hukumnya bila sebagai walinya ditunjuk orang lain oleh Ayah kandung secara langsung, setidaknya atas izin dan kewenangan yang diberikan.

\subsection{Wakil Suami}


Selain Ayah kandung yang boleh diwakilkan, dalam syariat Islam sebenarnya bisa saja perwakilan itu dilakukan oleh pihak menantu atau calon suami. Seorang calon suami boleh meminta orang lain untuk bertindak sebagai wakil atas namanya dirinya, dalam perkara ijab kabul. Asalkan permintaan itu dilakukan secara benar dan sesuai dengan prosedur. Maka tindakan si wakil dalam hal ini sah menurut hukum syariah.

\subsection{Wakil Wali vs Wakil Suami}

Bisa saja masing-masing pihak meminta orang lain menjadi wakil. Ayah kandung meminta orang lain menjadi wakil dirinya. Dan pihak calon suami juga meminta orang lain lagi untuk menjadi wakil atas dirinya. Lalu masing-masing wakil itu melakukan akad nikah atas nama dan atas seizin dari masing-masing pihak yang diwakilinya. Dan hal itu hukumnya sah dan dibenarkan dalam syariah Islam. Dan hal ini sangat lazim kalau kita lihat dari sudut pandang hukum. Bukankah dalam sebuah persidangan, baik terdakwa maupun penuntut sangat lazim menggunakan jasa lawyer (pengacara) profesional? Para pengacara ini kemudian bukan saja memberikan masukan dan advisnya, bahkan ikut berbicara di depan sidang pengadilan. Mereka berfungsi sebagai kuasa hukum. Maka hal yang sama juga berlaku dalam masalah akad nikah. Masing-masing pihak, baik calon suami atau pun wali, sama-sama berhak mengangkat orang lain untuk bertindak atas nama dirinya dalam sebuah akad nikah. Dan akad itu bisa sah secara hukum. Kecuali para saksi, justru mereka tidak boleh diwakilkan, karena fungsi saksi justru sangat penting peranannya sehingga tidak bisa diwakilkan. Tapi yang memudahkan, para saksi ini boleh siapa saja, tidak harus yang masih punya hubungan famili dengan masing-masing pihak. Maka dengan demikian, asalkan masingmasing pihak sudah terwakili secara sah, maka akad nikah itu bisa dilakukan secara sah, baik dalam hukum agama maupun dalam hukum negara. Baik akad itu dilakukan di Indonesia maupun di luar negeri.

\section{KESIMPULAN DAN SARAN}

Ditinjau dari dua sisi hukum yang berbeda yaitu hukum Negara dalam hal ini perundang-undangan Negara Republik Indonesia tentang perkawinan dan hukum syariat Islam, tentang permasalahan yang kadang terjadi di masyarakat yaitu tentang mempelai pria mewakilkan dirinya untuk menikah dikarnakan jarak dan lain hal, maka didapati hasil dari kedua hukum tersebut adalah sah dan diperbolehkan dengan ketentuan syarat yang berlaku.

\section{DAFTAR PUSTAKA}

Ar, Syamsuddin \& S. Damaianti, Vismaia. (2011). Metode Penelitian Pendidikan bahasa. UPI \& PT. Remaja Rosdakarya: Bandung.

Baharun, Segaf Hasan. (2005). Bagaimanakah Anda Menikah? dan Mengatasi Permasalahannya. Yayasan Pondok Pesantren Darullughah Wadda'wah.

Mahalli, A.Mujab. (2001). Menikahlah Engkau Menjadi Kaya. Mitra Pustaka. Yogyakarta.

McMilan, J. \& Schumacher, S. (2001). Research in Education. NewYork: London.

Sarwat, Ahmad. (2017). Seri Fikih Kehidupan (8) : Pernikahan. Rumah Fiqih Publishing. Jakarta.

Rasjid, Sulaiman. (2012) Fiqih Islam : Hukum Fiqih Lengkap, Sinar Baru Algae Sindo, Bandung.

Sarong, A.Hamid. (2010) Hukum Perkawinan Islam di Indonesia, Pena, Banda Aceh.

Hidayati, Taufik. (2013). Analisis Yuridis Peranan Wali Nikah Menurut Fiqih Islam dan Kompilasi Hukum Islam (Studi Putusan Mahkamah Agung Republik Indonesia No.261/K/AG/2009). Medan 


\section{I}

Jurnal Humaniora Teknologi

p-ISSN: 2443-1842

Volume 5, Nomor 2, Oktober 2019

. Hukum Perkawinan Islam di Indonesia: (2009) Antara Fiqh Munakahat dan Undang-undang Perkawinan, Kencana Prenada Media Group, Cetakan Ketiga, Jakarta.

http://hukum.unsrat.ac.id/ma/kompilasi.pdf. 